\title{
Visiting Bitter Gourd (Momordica charantia) from a Breeding Perspective: A Review
}

\section{Hari Kesh ${ }^{1}$ and Prashant Kaushik ${ }^{2,3 *}$}

${ }^{1}$ Department of Genetics and Plant Breeding, CCS Haryana Agricultural University, 125004 Hisar, India

${ }^{2}$ Institute of Conservation and Improvement of Valencian Agrodiversity, Polytechnic University of Valencia, 46022 Valencia, Spain

${ }^{3}$ Nagano University, 1088 Komaki, Ueda, 386-0031 Nagano, Japan

*Correspondence: prakau@doctor.upv.es

\begin{abstract}
Bitter gourd is an important vegetable of the family Cucurbitaceae, cultivated mainly in humid and subtropical Asia. Bitter gourd is vegetable with immense health benefits due to the presence of medicinal compounds such as charatin, vicine, and polypeptide-p, which play an essential role in lessening the blood glucose levels. Moreover, bitter gourd fruits are particularly rich in vitamin $\mathrm{C}$, minerals, and carotenes. Here, an effort has been made to critically evaluate the extent of achievements during the enhancement and enactment of bitter gourd breeding programs with the use of latest technologies. Broadening of the genetic base of cultivated bitter groud varieties as a result of enrichment of the existing resources by using the wild species in the breeding programs. Practical seed production technological know-how along with the use of the MS system (male sterility)/chemical-induced sterility procedure is nonetheless vital to cope up with the market demands. Superior yielding bitter gourd hybrids combining early maturity and resistance to biotic and abiotic stresses are regularly needed to cope up with the challenge of bitter gourd production.
\end{abstract}

Keywords: bitter gourd, breeding, genetic diversity, genomics, heterosis, molecular breeding, mutation breeding

\section{Introduction}

Momordica is one of the largest Genus in the Cucurbitaceae family. The genus includes 59 species distributed widely in Africa and Asia (de Wilde and Duyfjes 2002; Schaefer and Renner 2010). Out of 59 species, 34 species are dioecious, and 22 are monoecious while the remaining three are not clear whether they are dioecious or monoecious (Schaefer and Renner 2010). Two monoecious viz. M. charantia L. and M. balsamina L. and four dioecious viz. M. dioicaRoxb., M. sahyadrica, M. cochinchinensis and M. subangulata of genus Momordica (Joseph 2005). 
Momordica charantia cultivated as food as well as a medicinal plant in Asia, and Africa is the only cultivated species of in Momordica genus (Degner 1947; Walters and Decker-Walters, 1988). However, the recommended region of domestication for bitter gourd lies in eastern Asia especially in Southern China or India (Decker-Walters and Walters 1988; Decker-Walters and Robinson 1997; Marr et al. 2004), Fiji as well as the South Pacific (Smith, 1981) along with southwestern India (Joseph, 2005). The first history claimed the growing of M. charantia in China in 1370 CE (Walters and Yang, 1992). Bitter gourd is abundant in the phenolic acids (Kaushik et al., 2015). Nevertheless, there aren't any archaeological accounts of M. charantia continues to be in China (Yen 1977; Marr et al. 2004). Small-Fruited or wild cultivated crops with medicinal uses are quoted in Ayurvedic texts by Indo Aryan cultures (Decker Walters, 1999 ) indicating old growing of bitter gourd in India. Recent scientific studies proved that M. charantia was originated from Africa (Renner and Schaefer, 2010). Both domesticate, and crazy progenitors of M. charantia are cited in floras of India, tropical Africa and Asia.

The domesticate was believed to arrive from Africa to Brazil with the slave trade then dispersed to Central America (Ames 1939; Marr et al. 2004). Wild sorts of bitter gourds are green to dark blue, spiny, brief and very bitter and abundantly present in Northeastern India (Gaikwad et al., 2008). Based on historical, scientific studies (Chakravarty 1990; Miniraj et al. 1993; Decker-Walters and Walters 1988) along with molecular analysis (Dey et al. 2006a; Singh et al. 2007; Gaikwad et al. 2008),

eastern India (Orissa, West Bengal, Assam, Jharkhand, and Bihar) may be considered as the primary centre of diversity. Diversity analysis based on simple sequence repeat markers among Asian collections of bitter gourd landraces and hybrids showed that South Asia is the centre of domestication of bitter gourd (Dhillon et al., 2016). M. charantia is a commercial crop grown commercially in India, China, Japan, Malaysia, Thailand, Philippines, Australia, Tropical Africa and South America. Here, an effort has been made to critically evaluate the extent of achievements during the enhancement and enactment of bitter gourd breeding programs with the use of latest technologies.

\section{Genetic diversity}

The importance of genetic diversity in any crop germplasm is well recognized as they provide the basic raw material for selection and hybridization program of plant breeding and crop improvement. The evolution of transgressive segregants in the hybridization program largely depends on the availability of diverse germplasm in the gene pool of a crop. A great level of diversity present in both cultivated and wild relatives of Momordica genus for several important traits. Although interspecific crosses were not successful between these two species 
(Joseph 2005). However, the formation of bivalents during normal meiotic cycle suggested that these two species are phylogenetically similar (Singh 1990). Germplasm which leads to partial fertility upon hybridization comes under the secondary gene pool. Gene pool 2 includes $M$. dioica, M. sahyadrica, M. subangulata subsp. renigera, and M. cochinchinensis. Except for two viz., $M$. cochinchinensis $\times M$. dioica and $M$. cochinchinensis $\times$ M. sahyadrica, a successful, viable seed setting was observed between all possible combinations of dioecious species (Bharathi, 2010).

A lower seed set and germination were observed when diploid species was used as a female parent while a proper seed setting was reported when tetraploids species was used as a female parent. M. subangulata subsp. renigera, a tetraploids species showed high fruit setting when crossed with diploid species $M$. sahyadrica and $M$. dioica while in the reverse cross of $M$. sahyadrica and $M$. dioica with $M$. subangulata subsp. renigera, the fruit setting was comparatively low (Brar et al., 2019; Behera et al., 2020). Tertiary gene pool includes species which are distantly related to each other and gene exchange between them is impossible except by using some special techniques such as embryo rescue, somatic hybridization, bridging cross and genetic engineering. Tertiary gene pool includes $M$. cymbalaria, which did not show ant seed setting when hybridized with the rest of the species of Momordica genus (Behera et al., 2020).M.charantia shows a tremendous amount of diversity for various morphological and quality traits. Fruits of wild type plants are generally smaller in size, pointed at both the ends and produced small grey to black seeds while of cultivated plants have fruits of different shapes and size with length ranged up to $60 \mathrm{~cm}$ and produced large brown seeds (Walters and DeckerWalters 1988; Yang and Walters 1992). Significant variation was observed for earliness-related traits by Dey et al. 2009 and Khan et al. 2015. Diversity for ascorbic acid (60.20 mg to 122.07 $\mathrm{mg} / 100 \mathrm{~g}$ ) among bitter gourd accessions was observed by Dey et al. (2005). Chemical and nutritional composition study of light green small, light green big, dark green small, and dark green big type of bitter gourd revealed that highest carbohydrate and fiber content were found in the light green small types (8.22 and $1.21 \mathrm{~g}$ ) (Krishnendu and Nandini, 2016).

The critical traits for bitter gourd are earliness, number of fruits per plant, fruit length, fruit girth, number of female flowers per plant, number of days taken for first female flower emergence, fruit weight, fruit colour, bitterness, fruit yield per plant, disease and insect resistance etc. Light brown seed coat colour is recessive to deep brown (Nath and Srivastava 1972; Ram et al. 2006); Large seed size is recessive to small seed size (Nath and Srivastava 1972); white-coloured epicarp is recessive to eco friendly (Suribabu et al. 1986; Vahab 1989); spiny fruit is dominant over sleek (Vahab 1989); Green fruit colour is actually dominant over 
yellow (Hu et al., 2002) and is managed by 2 genes (Liu et al., 2005). The bitterness of fruit is a monogenic characteristic, with much more bitterness is actually dominant over less (Suribabu et al., 1986; Dalamu et al. 2012). The monogenic inheritance was described for fruit colour, fruit lustre, fruit area system, and stigma colour, but a digenic form of inheritance was suggested for seed colour (Kole et al. 2012). Nath and Srivastava (1972) discovered immature fruit colour in bitter gourd was managed by one nuclear gene without any cytoplasmic element involved. The light green colours were most likely influenced by incomplete dominance or maybe modifier genes ( $\mathrm{Hu}$ et al. 2002). The constant perturbation in fruit length indicated its quantitative inheritance and over 4 genes had been reported to be engaged in managing this particular trait (Kumari et al. 2015). The quite short fruit length is partly dominant, and curviness and tubercles of fruits in bitter gourd, governed by a single pair of a nuclear gene as well as the tubercles trait (Kumari et al. 2015). Expression of gynoecious trait in the bitter groud was discussed (Iwamoto and Ishida, 2006) partly dominating in Japanese germplasm of sour gourd while in Indian germplasm of bitter gourd Ram et al.et al. (2009) observed gynoecy (gy1) is, in fact, recessive to monoecy. Genetic analysis by Kim and Kim 1990 showed that small fruit size was partially dominant to large fruit size. Complementary epistasis and dominance $\times$ dominance gene interaction were important determinates of fruit yield in bitter gourd Singh and Ram (2005). Inheritance of resistance to melon fruit fly indicates that fruit fly resistance is dominant over susceptibility (Tewatia and Dhankhar 1996).

\section{Heterosis breeding}

Degree of heterosis depends on the genetic divergence between parents involved in the cross, their mode of reproduction, traits to be studied and the plant developmental stage. This hypothesis suggests that heterozygosity at individual loci as leading to heterosis. Heterosis is mainly utilizing dominance variation (Kumar et al., 2020). The exploitation of heterosis is more feasible in bitter gourd due to its cross-pollinated nature. The crucial points for the exploitation of heterosis are the identification of superior and divergent inbred lines, information on the combining ability of inbred lines and production of hybrid based on the pedigree and combining ability of inbred lines. It will be hugely beneficial to the breeder if a correlation could exist between the genetic distances of hybrid parents and the yield obtained from their respective cross or hybrid. Molecular markers can be used for prediction of heterosis based on genetic diversity of parental lines was earlier demonstrated in several other crops, like in rice (Xie et al., 2013). The preferable parameters to satisfy the consumer demands are soft fruits with a smaller number of seeds, minimized ridges, uniform green colour, high vigour, a more 
significant number of female flowers, good fruit setting and high yield (Al-Mamun et al., 2015). However, consumer preference is varied in region wise.

Light green, medium-long, spindle fruit are preferred in Vietnam, during long cylindrical and smooth fruit and light-green in Thailand. South Asian consumers like small-to-medium size, dark-green, spindle-shaped fruit with spiny exterior surfaces. In Taiwan and India, white fruit is used in soups (Dhillon et al., 2016). A lot of variabilities was noticed for vegetative and fruit figures in bitter gourd. Due to the presence of large variability, monoecious characteristics, convenient and conspicuous flowers along with a substantial selection of seeds per fruit bitter gourd work as a prospective crop for the exploitation of heterosis (Thangamani and Pugalendhi, 2013). As bitter gourd does not show or very negligible inbreeding depression, the homozygous inbred lines developed after 6 to 7 generation of continuous selfing. Before making the crosses between inbred lines directly, information regarding the general and specific combining ability will help the breeder in getting the superior hybrids (Haripriya, 1991). High general combining ability effects for different characteristics may help identify better parents with favourable alleles for different components of yield (Acharya et al., 2019). Thus, a substantial general combining capability of the parents appears to be a dependable criterion for the prediction of certain combining ability (Sidhu and Brar, 1977). In Bitter gourd, heterosis continues to be noticed for days to very first female flowering, fruit per yield and vine per vine (Vahab, 1989), vine measurements, fruit measurements, as well as yield per vine Devadas (1993), fruit fat as well as yield per vine (Richard et al., 1995), vine length, days to first female flowering, fruit length and fruit number Celine and Sirohi (1996), fruit flesh thickness and fruits per vine (Jadhav, 2009), node at which first female flower appeared and fruit length (Thangmani and Pugalendhi, 2013), days to first harvest and number of fruits per plants (Al-Mamun et al., 2015) (Table 1).

Table 1: Review of literature on magnitude of heterosis (\%) over the mid parent, and better parent values for yields and it's component trais in bitter gourd.

\begin{tabular}{|l|l|l|l|}
\hline Characters & Mid parent & Better parent & References \\
\hline Vine length & 1.66 to 23.37 & & $\begin{array}{l}\text { Sirohi and Choudhary } \\
(1978)\end{array}$ \\
\hline & 2.10 to 22.30 & & Singh and Joshi (1980) \\
\hline & 4.26 to 57.81 & & Chaudhari and Kale (1991b) \\
\hline
\end{tabular}




\begin{tabular}{|c|c|c|c|}
\hline & 0.99 to 20.98 & 1.41 to 4.21 & Munshi and Sirohi (1993) \\
\hline & -8.31 to 29.81 & -24.51 to 2.20 & Yadav et al., 2009 \\
\hline & -42.56 to 111.74 & -45.10 to 49.08 & Talukdar et al., 2010 \\
\hline & -6.00 to 15.90 & & Behera et al., 2009 \\
\hline & & -34.60 to 30.72 & Talekar et al., 2013 \\
\hline & & -32.57 to 57.48 & Verma and Singh, 2014 \\
\hline \multirow[t]{5}{*}{$\begin{array}{l}\text { Number of } \\
\text { primary } \\
\text { branches/vine }\end{array}$} & 7.80 to 37.00 & & Singh and Joshi (1980) \\
\hline & 3.30 to 25.85 & & Singh et al. (1997) \\
\hline & -30.46 to 251.77 & -11.21 to 293.65 & Yadav et al., 2009 \\
\hline & & -26.23 to 13.70 & Talekar et al., 2013 \\
\hline & -47.37 to 182.35 & -50.00 to 140.00 & Talukdar et al., 2010 \\
\hline \multirow[t]{3}{*}{ Internodal length } & -21.92 to 20.66 & -34.34 to 16.44 & Yadav et al., 2009 \\
\hline & & -21.13 to 20.00 & Talekar et al., 2013 \\
\hline & -39.31 to 22.36 & -42.53 to 19.16 & Talukdar et al., 2010 \\
\hline \multirow[t]{4}{*}{$\begin{array}{l}\text { Days to opening } \\
\text { of the first male } \\
\text { flower }\end{array}$} & -8.29 to -26.8 & & Singh et al. (2000) \\
\hline & -1.09 to 12.09 & -7.43 to 8.51 & Yadav et al., 2009 \\
\hline & -27.22 to 9.80 & -29.79 to 7.33 & Talukdar et al., 2010 \\
\hline & & -17.83 to 10.64 & Talekar et al., 2013 \\
\hline \multirow[t]{3}{*}{$\begin{array}{l}\text { Days to opening } \\
\text { of the first female } \\
\text { flower }\end{array}$} & 54.00 to 66.00 & & Lawande and Patil (1989b) \\
\hline & & -15.72 to 7.48 & Ram et al. (1997) \\
\hline & & -0.12 to -6.50 & Singh et al. (2001) \\
\hline
\end{tabular}




\begin{tabular}{|c|c|c|c|}
\hline & & -0.22 to -29.51 & Kandasamy (2015) \\
\hline & -17.65 to 3.08 & -23.00 to -2.22 & Yadav et al., 2009 \\
\hline & & -19.34 to 14.47 & Talekar et al., 2013 \\
\hline & -18.46 to 10.77 & -23.89 to 3.94 & Talukdar et al., 2010 \\
\hline & & -9.17 to 34.86 & Verma and Singh, 2014 \\
\hline \multirow{9}{*}{$\begin{array}{l}\text { Days to first fruit } \\
\text { harvest }\end{array}$} & -0.42 to 15.06 & & Sing et al. (1997) \\
\hline & -6.19 to -22.20 & & Singh et al. (2000) \\
\hline & & & Chaubey and Ram (2004) \\
\hline & -26.82 to -17.90 & & Behera et al., 2009 \\
\hline & & -1.4 to -26.3 & Al-Mamun et al. (2015) \\
\hline & & -17.27 to 11.20 & Talekar et al., 2013 \\
\hline & -11.91 to 4.66 & -16.42 to -0.14 & Talukdar et al., 2010 \\
\hline & -19.80 to 3.60 & & Dey et al., 2010 \\
\hline & & -19.33 to 7.69 & Verma and Singh, 2014 \\
\hline \multirow{6}{*}{$\begin{array}{l}\text { Number of fruits per } \\
\text { plant }\end{array}$} & 0.86 to 44.44 & 0.39 to 35.02 & Munshi and Sirohi (1993) \\
\hline & & -66.67 to 30.61 & Ram et al. (1997) \\
\hline & & 0.0 to 104.7 & Al-Mamun et al. (2015) \\
\hline & & -32.23 to 22.99 & Talekar et al., 2013 \\
\hline & 74.12 to 100.23 & & Dey et al., 2010 \\
\hline & & 39.86 to 32.43 & Verma and Singh, 2014 \\
\hline \multirow[t]{9}{*}{ Fruit length } & & 0.90 to 17.75 & Khattra et al. (1994) \\
\hline & & 1.40 to 25.46 & Singh et al. (2001) \\
\hline & 31.27 to 37.00 & & Behera et al., 2009 \\
\hline & & -37.7 to 6.8 & Al-Mamun et al. (2015) \\
\hline & & 1.43 to 39.79 & Kandasamy (2015) \\
\hline & -37.57 to 4.87 & -30.95 to 20.76 & Yadav et al., 2009 \\
\hline & -18.17 to 15.01 & -20.24 to 12.38 & Talukdar et al., 2010 \\
\hline & & -38.08 to 39.11 & Talekar et al., 2013 \\
\hline & 4.65 to 13.80 & & Dey et al., 2010 \\
\hline
\end{tabular}




\begin{tabular}{|c|c|c|c|}
\hline & & 29.72 to 17.99 & Verma and Singh, 2014 \\
\hline \multirow[t]{7}{*}{ Fruit diameter } & & -11.7 to 13.4 & Al-Mamun et al. (2015) \\
\hline & & 1.07 to 25.34 & Kandasamy (2015) \\
\hline & 20.90 to 37.60 & & Behera et al., 2009 \\
\hline & -24.19 to 23.88 & -22.73 to 39.53 & Yadav et al., 2009 \\
\hline & 2.30 to 10.50 & & Dey et al., 2010 \\
\hline & -5.58 to 7.09 & -8.37 to 4.95 & Talukdar et al., 2010 \\
\hline & & -36.57 to 41.08 & Verma and Singh, 2014 \\
\hline \multirow[t]{4}{*}{ Fruit weight } & 5.00 to 14.50 & & Dey et al., 2010 \\
\hline & & -18.60 to 9.38 & Verma and Singh, 2014 \\
\hline & 26.75 to 46.38 & & Behera et al., 2009 \\
\hline & -10.41 to 29.97 & -29.17 to 28.67 & Talukdar et al., 2010 \\
\hline \multirow[t]{3}{*}{ Flesh thickness } & & & Ranpise et al. (1992) \\
\hline & 6.13 to 16.26 & 1.47 to 6.27 & Celine and Sirohi (1996) \\
\hline & -17.11 to 29.66 & -25.19 to 26.87 & Mallikarjunarao (2018) \\
\hline \multirow[t]{9}{*}{ Fruit yield per plant } & & 4.35 to 64.28 & Khattra et al. (1994) \\
\hline & & 19.7 to 102.0 & Al-Mamun et al. (2015) \\
\hline & 132.00 to 142.20 & & Behera et al., 2009 \\
\hline & -8.35 to 113.01 & -22.80 to 94.25 & Talukdar et al., 2010 \\
\hline & & 0.38 to 60.38 & Kandasamy (2015) \\
\hline & -34.75 to 23.10 & -10.29 to 58.51 & Yadav et al., 2009 \\
\hline & -30.22 to 136.43 & -43.64 to 98.75 & Mallikarjunarao (2018) \\
\hline & & -58.96 to 51.14 & Talekar et al., 2013 \\
\hline & 38.22 to 97.49 & & Dey et al., 2010 \\
\hline
\end{tabular}




\begin{tabular}{|l|l|l|l|}
\hline & & -39.41 to 35.23 & Verma and Singh, 2014 \\
\hline $\begin{array}{l}\text { Vitamin C content } \\
(\mathrm{mg} / 100 \mathrm{~g})\end{array}$ & -11.60 to 29.03 & -16.15 to 24.75 & Mallikarjunarao (2018) \\
\hline \multicolumn{1}{|c|}{ content } & -23.43 to 52.34 & -34.62 to 36.97 & Kumar and Pathak, 2018 \\
\hline \begin{tabular}{l} 
Iron content $/ 100 \mathrm{~g})$ \\
\hline $\begin{array}{l}\text { TSS }\left({ }^{\circ} \mathrm{Bri} \times\right) \\
\text { Carotene }\end{array}$
\end{tabular} & -23.50 to 27.37 & -34.44 to 20.18 & Mallikarjunarao (2018) \\
\hline $\begin{array}{l}\text { Total sugar }(\mathrm{g} / 100 \mathrm{~g}) \\
\text { Reducing }\end{array}$ & -79.61 to 52.92 & Kumar and Pathak, 2018 \\
\hline sugar(g/100g)
\end{tabular}

\section{Mutation breeding}

The mutation may occur spontaneously, or it can be induced artificially. Artificial mutations can be induced by physical mutagens such as X-rays, y-rays and neutrons and by chemical mutagens such as ethyl methanesulfonate (EMS) (Ahloowalia and Malugzgnslia, 2001). Physical mutagens are used more frequently than chemical mutagens, and among physical mutagens, y-rays are used more commonly than X-rays (Beyaz and Yildiz, 2017). Mutation breeding has become a powerful technique for developing novel plant genotypes (Penna et al., 2012). Mutation screening is the selection of individuals from a sizeable mutated population that meet specific selection criteria, and mutant confirmation is re-evaluating (Oladosu et al., 2016). A Bitter gourd landrace MC 013 was treated with gamma radiation and developed a new cultivar MDU 1 which possesses improvement for yield, long greenish white fruits, tolerance to pumpkin beetle, fruit fly and leaf spot diseases (Rajasekharan and Shanmugavelu 1984). Similarly, a white-fruited type mutant Pusa Do Mausami was developed from a natural population of green fruited type Pusa Do Mausami variety (Behera et al., 2010).

\section{Interspecific Hybridization}

The Inter-specific and intra-specific hybridization has an essential role in tracing the genomic relationship and improving crops by transferring desirable agronomic characters and 
some specific traits such as disease, pests and stress resistance from wild relatives to cultivated ones (Bowely and Taylor, 1987). In Momordica, studies were carried out on inter-specific hybridization to establish phylogenetic relationships (Vahab 1989). Crossability studies among different species of Momordica such as M. dioca, M. cochinchinensis and M. subtangulatas ubspp. renigera was reported by Bharathi et al., (2011). The hybrids were observed as intermediated for ovary colour, fruit shape and colour, number of seeds and distribution of trichomes on stem and leaves (Hassena and Suhara, 2012). High crossability and pollen fertility were observed between inter-varietal cross $(M$. charantia var. charantia $\times M$. charantia var. muricata).

In contrast, low crossability and moderate pollen fertility were observed in the interspecific $\operatorname{cross}(M$. charantia $\times$ M. balsamina). Similarly, Rathod et al., (2019) attempted interspecific crossing for the characterization of plant morphology, pollen-pistil compatibility cytology and molecular relationships among parents and hybrids. Both direct and reciprocal crosses showed an approximate $90 \%$ crossability with a good percentage of pollen viability.

An interspecific cross resulted in a hybrid between M. charantia variety PusaAushadi (Female) and M. balsamina (male) were selfed and backcrossed with Pusaaushadi and $M$. balsamina. Inheritance studies showed that a single dominant gene governed fruit tubercle, discontinuous ridges and green colour of fruit, seed coat colour was governed by semidominant gene, and gynoecia was governed by a single recessive gene (Annual report IARI2018-19, India). Crossability percentage among interspecific crosses in the bitter gourd is presented in Table 2.

Table 2: Crossability percentage among interspecific crosses in bitter gourd.

\begin{tabular}{|c|c|c|}
\hline Inter-specific combinations & $\%$ crossability & References \\
\hline $\begin{array}{l}\text { M. charantia var. charantia } \times M \text {. } \\
\text { charntiavar. muricata }\end{array}$ & $100 \%$ & \multirow[t]{2}{*}{$\begin{array}{l}\text { Hassena and Suhara, } \\
2012\end{array}$} \\
\hline $\begin{array}{l}\text { M. charntiavar. } \\
\text { charantiavar. charantia }\end{array}$ & $88.89 \%$ & \\
\hline $\begin{array}{l}\text { M. charantiavar. charantia } \times M . \\
\text { charntiavar. muricata }\end{array}$ & $97 \%$ & \multirow[t]{3}{*}{ Bharathi et al., (2012) } \\
\hline $\begin{array}{l}\text { M. charntiavar. } \\
\text { charantiavar. charantia }\end{array}$ & $85 \%$ & \\
\hline M. charntiavar. muricata $\times$ M. balsamina & $6 \%$ & \\
\hline
\end{tabular}




\begin{tabular}{|c|c|c|}
\hline M. dioca $\times$ M. sahyadrica & $75 \%$ & \\
\hline $\begin{array}{l}M . \quad \text { dioca } \times M . \quad \text { subangulatasubsp. } \\
\text { renigera }\end{array}$ & $53 \%$ & \\
\hline M. dioca $\times$ M. cochinchinensis & $60 \%$ & \\
\hline $\begin{array}{l}\text { M. } \quad \text { subangulatasubsp. } \quad \text { renigera } \times M . \\
\text { dioca }\end{array}$ & $65 \%$ & \\
\hline $\begin{array}{l}\text { M. } \quad \text { subangulatasubsp. } \text { renigera } \times M . \\
\text { sahyadrica }\end{array}$ & $84 \%$ & \\
\hline $\begin{array}{l}\text { M. } \quad \text { subangulatasubsp. } \text { renigera } \times M . \\
\text { cochinchinensis }\end{array}$ & $2 \%$ & \\
\hline $\begin{array}{l}\text { M. sahyadrica } \times \text { M. subangulatasubsp. } \\
\text { renigera }\end{array}$ & $50 \%$ & \\
\hline M. sahyadrica $\times$ M. dioca & $81 \%$ & \\
\hline M. sahyadrica $\times$ M. cochinchinensis & $65 \%$ & \\
\hline $\begin{array}{l}\text { M. } \quad \text { cochinchinensis } \times M . \\
\text { subangulatasubsp. renigera }\end{array}$ & $5 \%$ & \\
\hline $\begin{array}{l}\text { M. charantia var. charantia } \times M \text {. } \\
\text { charntiavar. muricata }\end{array}$ & $90.98 \%$ & Rathod et al., 2019 \\
\hline $\begin{array}{l}M . \quad \text { charntia var. } \text { muricata } \times M . \\
\text { charantiavar. charantia }\end{array}$ & $84.43 \%$ & \\
\hline
\end{tabular}

\section{Biotechnology}

Traditional breeding techniques for any crop improvement is time-consuming. Due to the increasing importance of bitter gourd the improvement and the development of new varieties are necessary, which could be done through the modern application of biotechnology (Sinha et al., 2019). The application of transgenic technology through gene manipulation opens the way for producing genotypes carrying important traits such as resistance against biotic and abiotic stresses. Plant tissue cultures are used for plant breeding, commercial production and basic biological research (Agarwal M., 2015). Types of explants, media composition, growth conditions, genotypes and physiological conditions of the explants affect callus induction and plant regeneration. Wang et al., 2008., established in vitro plant regeneration system from cotyledon node and showed that age of seedlings, the different combination of hormones, their concentration ratio and different genotypes results differently in the in vitro morphogenesis of 
M. charantia.The effect of various growth regulators was studied by Malik et al., 2007 on callogenesis and organogenesis of $M$. charantia. They observed that leaf explants showed maximum callus percentage as compared to stem and cotyledons.

Similarly, shoot tip explants showed best shooting response at 6-Benzyl Amino Purine (BAP) with Naphthalene acetic acid (NAA) supplemented in MS medium. BAP and Thidiazuron (TDZ) also produced good shooting response while BAP when used alone, the shooting response was low. Importance of BAP for proper callus development was also reported by (Berg et al., 1997). Similarly, for rooting the effectiveness of Indole-3-butyric acid (IBA) in M. dioica (Hoque et al., 1995), NAA in Cucurbita pepo (Kathiravan et al., 2006) and Indole-3-acetic acid (IAA) in M. dioica (Han et al., 2004) has been reported. An efficient and simple plant regeneration process from the cultured cell is necessary for getting plant transformation procedures (Yang and Thiruvengadam, 2009). Few in the past regrowth protocol of M. charantia were reported from various explants like cotyledons (Islam et al., 1994), nodal and shoot tissues (Wang et al., 2001; Malik et al., 2007), intermodal and nodal explants (Kamal and Agarwal, 2004), somatic embryogenesis (Thiruvengadam et al., 2006) along with petiole explants (Yashodhara et al., 2016). Among the generally used approaches of gene transfer, the Agrobacterium-mediated gene transfer strategy is seen as most effective for the healthy integration of genes into the host plant genome. Agrobacterium-mediated $b$ glucuronidase gene expression was recognized in explants of immature cotyledonary nodes in M. charantia (Sikdar et al. 2005) as well as leaf disc (Thriruvengadam et al., 2012).

\section{Gynocism in bitter gourd}

- Gynoecious lines have a better genetic combining ability, and gynoecious $\times$ monoecious hybrids mature early with higher yield potential (Dey et al., 2010). Thus, gynoecious line can easily be utilized for the hybrid seed generation in bitter gourd as it stays away from the mechanical emasculation and pollination. The main sex type in the bitter gourd is actually monoecious; however, gynoecious sex type has been reported from India, China and Japan (Behera et al., 2006). For the very first time, bitter gourd crops with an entire phrase of gynoecious flowering habit (only pistillate blossoms on a plant) have been put in 3 gynoecious collections namely Gy23 Gy63 and Gy263B (Ram et al. 2002a). And then, many populations with an extremely high proportion (more than ninety \%) of pistillate blossoms have been designed (Ram et al. 2002b). 2 gynoecious lines viz., DBGy-202 and DBGy-201 are isolated from its vivid relatives M. charantia var. muricata L. (Behera et al., 2006). These lines have been recognized for the inheritance of development and gynoecia of hybrid cars (Behera et al., 2009). They hold great potential in future breeding plans for the improvement of earliness and 
yield in bitter gourd (Varalakshmi et al., 2014). Gynoecium is actually under the command of an individual recessive gene (gy 1) (Ram et al., 2006; Behera et al., 2009), whereas Ishida and Iwamoto (2006) found that gynoecious sexexpression in bitter gourd is partly dominant. 2 pairs of Genes described by Cui et al., 2018 Moreover, the subsequent decades (including F1) utilizing gynoecious as a single parent showed an extremely high percent of pistillate (female) blossoms (Ram et al., 2002a; Behera et al., 2006; Ishida and Iwamoto, 2006).

In Okinawa, a gynoecious line (OHB61-5) was identified, which was supposed to be a spontaneous mutant. This line, when crossed with OHB95-1A (monoecy) and F2 progenies studied, indicating that the trait was governed by a single recessive gene (Matsumura et al. 2014). High yielding hybrids between gynoecious $\times$ monoecious have recently become available (Behra et al., 2010). For example, the popular hybrid bitter gourd VNR 28, after transplanting in the last week of March in Chhattisgarh, India in 2012, produced only pistillate flowers continuously from the first week of May through the end of May. Still, staminate flowers did not appear until the end of May (Dhillon et al., 2017).

Similarly, 'Kumaken BP1', an early high yielding hybrid of bitter gourd in Japan developed using a gynoecious inbred line as the seed parent, needs a pollenizer for more initial fruit setting (Iwamoto et al., 2009). Lack of staminate flowers for pollination at the first appearance of open pistillate flowers delays or reduce the early and total fruit yield. Thus, adapted monoecious lines when blended with gynoecious $\times$ monoecious hybrids that produce pistillate flowers earlier than staminate flowers (Dhillon et al., 2017).

For transgressive segregants form, NBGH-167 cultivar were isolated. The lines development through progeny row method takes four consecutive generations of selfing for obtaining complete gynoeciouse $\times$ pression (Jadhav et al., (2018). For the maintenance of gynoecious line, the induction of male flower is essential. For the effective induction staminate flower, the gynoecious lines were treated with silver nitrate, silver thiosulphate and Gibbrelic acid. Silver Nitrate (AgNO3) performs well as compared to GA3 and Silver Thiosulphate $[\mathrm{Ag}(\mathrm{S} 2 \mathrm{O} 2) 2]$ for induction of male flowers in gynoecious line (Jadhav et al., (2018). Silver nitrate inhibits the synthesis of ethylene and thus induce staminate flower (Krishnamoorthy, 1975; Saha and Behera, 2015).

Identification of molecular marker associated with gynoecy trait is of great importance to determine the cost-effective hybrid seed production (Gaikwad et al., 2014). In the F2 population from OHB61-5 (gynoecious line) $\times$ OHB95-1A (monoecious line), a linkage map was constructed, and five single nucleotide polymorphism (SNP) loci were found linked to gynoecy. One of the SNP markers GTFL-1 was located at 5.46 cM distance (Matsumura et al. 
2014). Similarly, gy-1, a gynocious gene flanked bybTP_54865, and TP_54890 markers were mapped on LG 12 (Rao et al., 2018).

\section{Molecular breeding in bitter gourd}

Traditional plant breeding techniques are primarily depending on the phenotypic screening of germplasm lines. These techniques require a more extended period of time for diversity analysis, identification of desirable parents and took a long time for the improvement of essential traits. Genetic diversity grounded on quantitative characteristics has been completed in a bitter gourd by Mishra et al., (1998) and Ram et al., (2000). But genetic diversity among different lines can be done by molecular markers also. Molecular markers are independent of environmental conditions and show a higher level of polymorphism. The initial study on diversity analysis in bitter gourd was done by Dey et al., 2006. They evaluated 38 bitter gourd lines, including commercial cultivars collected from different parts of India using RAPD primers. Out of 116 primers, 29 were found polymorphic and informative.

The primary reason for mismatch might be that the majority of the quantitative traits are actually managed by a big selection of genes and are highly affected by locations (Dey et al., 2006). Ferriol et al., 2003 additionally didn't found some correlation between morphological and RAPD characterization in strawberry. The inter-simple sequence does this (ISSR) markers had been implemented the expose polymorphism among thirty-eight lines of M. charantia collected from various agro-ecological zones of India. The dendrogram analysis showed that 38 genotypes were grouped into 2 major groups with 36 genotypes in one group and 2 genotypes in the second group. RAPD markers had been worn by Rathod et al. (2008) for learning the genetic relationships among twenty genotypes of $M$. charantia.The genotypes were divided into two clusters, cluster A with one genotype and cluster B with 19 genotypes. Cluster B was further divided into two sub-clusters B1 (one genotype and B2 (18 genotypes). The RAPD and ISSR marker (Dey et al., 2006; Singh et al., 2007) used for diversity analysis could not provide complete insights into the cultigens examined (Gaikwad et al., 2008). The discriminating power of AFLP marker is generally higher than that of RAPD and ISSR (Powell et al., 1996; Vos et al., 1995) due to high polymorphic nature, broad distribution throughout the genome and high multiplex ratio (Milbourne et al., 1997).

The genetic relationships among 38 bitter gourd lines originating from different geographical regions were studied by Gaikwad et al., 2008. The results indicated that these lines could be used directly as parents in hybridization or as germplasm for selection to improve economically important trait (Fan et al., 2006; Fazio et al., 2003; Gao et al. 2010). The genotypes were divided into three main clusters and six sub-groups using RAPD markers and 
three main clusters and seven subgroups based on ISSR markers. The characterization by high polymorphism, simple sequence repeats (SSRs) are an ideal genetic markers and have gained significant importance in plant breeding (Akkaya et al. 1992; Morgante and Olivieri 1992; Peakall et al. 1998; Gupta et al. 1996). Guang-guang et al. (2013) studied genetic diversity and relationship among 50 bitter gourd varieties using 16 pairs of SSR primers. The genotypes were classified into 6 groups using UPGMA methods (Saxena et al. 2014). Since marker-assisted selection (MAS) is useful in the breeding of crops, genetic mapping of agronomically important traits directly contribute to the breeding programs (Kole and Abbott 2008). The first genetic map in bitter gourd was developed Kole et al. (2012) in the $F_{2}$ population between Taiwan White $\times$ CBM12 using AFLP markers. Subsequently, Wang and Xiang (2013) developed a linkage map in $F_{2}$ population of Z-1-4 $\times 189-4-1$ with the use of different kinds of molecular markers such as simple sequence repeat (SSR), AFLP, and sequence-related amplified polymorphism (SRAP). A list of QTLs identified for important traits in bitter gourd (Table 3).

Table3: List of QTLs identified for important traits in bitter gourd.

\begin{tabular}{|c|c|c|c|}
\hline Traits & Number of QTLs & Linkage group & References \\
\hline Fruit colour & 1 & LG 7 & \multirow[t]{7}{*}{ Kole et al. (2012) } \\
\hline Seed colour & 2 & LG 3 & \\
\hline Fruit length & 2 & LG 2 and LG 7 & \\
\hline Fruit diameter & 1 & LG 1 & \\
\hline Fruit weight & 1 & LG 1 & \\
\hline Fruit number & 4 & LG 1, LG 2 and LG 5 & \\
\hline Fruit yield & 4 & LG 1, LG 2 and LG 3 & \\
\hline $\begin{array}{l}\text { Sex ratio (Male: } \\
\text { female }\end{array}$ & 9 & $\begin{array}{l}\text { LG 9, LG 13, LG } 14 \text { and LG } \\
16\end{array}$ & \multirow{4}{*}{$\begin{array}{l}\text { Gangadhara Rao et } \\
\text { al. } \\
(2018)\end{array}$} \\
\hline $\begin{array}{ll}\text { Days to first } \\
\text { pistillate flower } \\
\text { appearance }\end{array}$ & 8 & $\begin{array}{l}\text { LG 3, LG 5, LG } 14 \text { and LG } \\
16\end{array}$ & \\
\hline $\begin{array}{l}\text { The node at first } \\
\text { pistillate flower } \\
\text { appearance }\end{array}$ & 5 & LG 5, LG 9 and LG 14 & \\
\hline Gynoecy & 1 & LG 12 & \\
\hline
\end{tabular}




\begin{tabular}{|c|c|c|c|}
\hline $\begin{array}{l}\text { Female flower } \\
\text { ratios }\end{array}$ & 3 & LG 4, LG 5 and LG 9 & \multirow[t]{13}{*}{$\begin{array}{l}\text { Wang and Xiang, } \\
2013\end{array}$} \\
\hline $\begin{array}{l}\text { First female flower } \\
\text { node }\end{array}$ & 3 & LG 4, LG 5 and LG 9 & \\
\hline Fruit length & 4 & LG 1, LG 2, LG 5 and LG 9 & \\
\hline Fruit diameter & 5 & LG 1, LG 9 and LG 11 & \\
\hline Flesh thickness & 2 & LG 1 & \\
\hline Fruit shape & 5 & LG 4, LG 5, LG 9 and LG 11 & \\
\hline Fruit pedicel length & 3 & LG 4, LG 8 and LG 9 & \\
\hline $\begin{array}{l}\text { Fruit pedicel length } \\
\text { ratios }\end{array}$ & 5 & LG 4, LG 6 and LG 8 & \\
\hline Fruit weight & 4 & LG 4, LG 5, LG 6 and LG 12 & \\
\hline $\begin{array}{l}\text { Fruit numbers per } \\
\text { plant }\end{array}$ & 3 & LG 1 and LG 5 & \\
\hline Yield per plant & 2 & LG 5 and LG 9 & \\
\hline Stem diameter & 2 & LG 2 and LG 4 & \\
\hline Internode length & 2 & LG 2 and LG 5 & \\
\hline Gynoecy & 2 & $\mathrm{MC} 01$ & \multirow[t]{8}{*}{ Cui et al., 2018} \\
\hline $\begin{array}{l}\text { First female flower } \\
\text { node }\end{array}$ & 2 & $\mathrm{MC} 01$ & \\
\hline $\begin{array}{l}\text { Female flower } \\
\text { number }\end{array}$ & 2 & $\mathrm{MC} 01$ & \\
\hline Fruit wart & 1 & $\mathrm{MC04}$ & \\
\hline Width of ridge & 1 & MC10 & \\
\hline Hue angle & 1 & MC10 & \\
\hline Lightness variable & 1 & MC10 & \\
\hline Bitterness & 3 & LG 3 and LG 4 & \\
\hline
\end{tabular}




\section{Bitter Gourd Genome}

The draft of the bitter gourd genome was generated with the inbred line, OHB3-1, by employing Illumina sequencing with an estimated size of $339 \mathrm{Mb}$ (Urasaki et al., 2017). Overall, 45,859 protein-coding genes were determined and based on the synteny bitter gourd was determined to be more closely related to watermelon (Citrullus lanatus) as compared to cucumber or melon. Interestingly, it was determined that trypsin-inhibitor and ribosomeinactivating genes were the notable characteristics in the bitter gourd genome (Yilmaz and Khawar, 2020) . These genes provide medicinal benefits properties to the bitter gourd. The genome of bitter gourd is assembled moreover a chromosome-level assembly, is also available with a maximum contig N50 (close to $10 \mathrm{Mb}$ ). The new version of bitter gourd genome based on the nanopore long-read assembler was published with a claim of the complete assembly of the Cucurbitaceae family (Matsumura and Urasaki, 2020). Based on the preference at a particular location phenotypic variations exists in the bitter gourd cultivars, e.g. in South-East Asia, small size fruits with bitter taste are preferable. Based on the genome assembly, it was formulated that the South Asian varietal group diverged from the progenitors around 6000 years ago (Matsumura et al., 2019).

\section{Conclusions and future prospects}

Bitter gourd produces large flowers and the techniques used for the hybrid development are well established in the bitter gourd and as similar to the ones for melon and cucumber. Further inbreeding or selfing is performed for several generations to produce the uniformity in the inbreds before their crossing to develop them into hybrids. Moreover, there is not any significant inbreeding depression in the bitter gourd; therefore, inbreds are regularly maintained by selfing. Further inbred testing is performed for their combining ability via employing several matting designs Line by Tester analysis, diallel analyses, etc.

It is further based on the obtained information regarding the general and specific combining abilities, most promising parents are chosen for the hybrid production. With the availability of bitter gourd genome and detailed genetic map, the selection for heterosis related alleles can be easily achieved in the bitter gourd improvement program. 
Moreover, to exploit heterosis in bitter gourd, it should not be only for yield but in line with the interest of other important traits such as climate change and also a mix of traits like insect pest and disease resistance. In this direction, crop wild relatives (CWR) can play an important role as they are the storehouse of important genes desired for the improvement of yield as well as stress tolerance. Bitter gourd is especially vital to countries like in South East Asia where the population is still poor and can not afford the medications for the treatment of their chronic illness. There is considerable reliance on the plants with therapeutic potential, and bitter gourd has been proved as a cure for many chronic diseases. We hope the use of bitter gourd likewise will increase in the western world and feature some significant research roads which ought to be organized. Failure to generate and provide a qualified amount of hybrid seed, specifically of general public bred hybrids warrants urgent notice.

\section{References}

1. Acharya, S.K., Kaushik, R.A., Ameta, K.D., Dubey, R.B., Upadhyay, B., 2019. Heterosis and combining ability in bitter gourd (Momordica charantia L.). Int. J. Bio. 8, 5692-5711. http://dx.doi.org/10.14303/ijbio.2019.8.1.3.

2. Agarwal, M., 2015. Tissue culture of Momordica charantia L.: A review. J. Plant Sci. 15, 2432. Doi: $10.11648 /$ j.jps.s.2015030101.14.

3. Agarwal, M., Kamal, R., 2004. In vitro clonal propagation of Momordica charantia L. Ind. J. Biotechnol. 3, 426-430.

4. Ahloowalia, B.S., Maluszynski, M., 2001. Induced mutations-A new paradigm in plant breeding. Euphytica 118, 167-173.

5. Akkaya, M.S., Bhagwat, A.A., Cregan, P.B., 1992. Length polymorphisms of simple sequence repeat DNA in soybean. Genetics 132, 1131-1139.

6. Al-Mamun, M.H., Rashida, M.H., Uddina, M.N., Islama, M.R., Asaduzzaman, M., 2015. Heterosis studies in bitter gourd. Int. J. Veg. Sci. https://doi.org/10.1080/19315260.2015.1072613.

7. Ames, O., 1939. Economic annuals and human cultures. Botanical Museum of Harvard University, Cambridge.

8. Behera, T.K., Dey, S.S., Munshi, A.D., Gaikwad, A.B., Pal, A., Singh, I., 2009. Sex inheritance and development of gynoecious hybrids in bitter gourd (Momordica charantia L.). Sci. Hort. 120, 130-33. https://doi.org/10.1016/j.scienta.2008.09.006.

9. Behera, T.K., Dey, S.S., Sirohi, P.S., 2006. DBGy-201 and DBGy-202: two gynoecious lines in bitter gourd (Momordica charantia L.) isolated from indigenous source. Ind. J. Genet. 66,6162.

10. Behera, T.K., Dey, S.S., Datta, S., Kole, C., 2020. Genetic resources and diversity in bitter gourd. In: Kole, C., Matsumura, H., Behera, T.K. (Eds.), The Bitter Gourd Genome, Compendium of plant genomes. Springer Nature Switzerland AG, pp. 45-59. 
11. Berg, A.J.W., Zhang, X.P., Rhodes, B.B., 1997. Microprapagation of Citrullus lanatus (Thumb) matsum and nakai (Water melon), in biotechnology in agriculture and forestry. HighTech and Micro Propagation., Bajaj, V.Y.P.S. (Eds.), Vol. 39. Springer-Verlag, Berlin Heidelberg.

12. Beyaz, R., Yildiz, M. 2017. The use of gamma irradiation in plant mutation breeding. Plant Engineering, Snjezana Juric, IntecOpen, DOI:10.5772/intechopen.69974.

13. Bharathi, L.K., Munshi, A.D., Behera, T.K., Vinod, John, J.K., Bhat, K.V., Das, A.B., Sidhu, A.S., 2012. Production and preliminary characterization of novel inter-specific hybrids derived from Momordica species. Curr. Sci. 103, 178-186.

14. Bharathi, L.K., Vinod, Munshi A.D., Behera, T.K., Shanti, C., Kattukunnel, J.J., Das, A.B., 2010. Cytomorphological evidence for segmental allopolyploid origin of teasel gourd (Momordica subangulata subsp. renigera). Euphytica 176, 79-85.

15. Bharathi, L.K., Vinod, Das, A.B., Ghosh, N., Behera, T.K., Nak, G., Nath, V., 2011. Cytomorphological and molecular characterization of interspecific F1 hybrid of Momordica dioica Roxb. X Momordica subangulata subsp. renigera (G. Don) de wilde. Afr. J. Agri. Res. 6, 2982-2990.

16. Bowley, S.R., Taylor, N.L., 1987. Introgressive hybridization, In: Christie, B.R. (Eds.), Handbook of Plant Science in Agriculture. CRC Press, Boca Raton, Florida, vol. 1, pp. 2359.

17. Brar, J.A., Sidhu, A.S., 1977. Heterosis and combining ability for earliness and quality characters in watermelon (Citrullus lunatus Thumb. Mansf.). Part II J. Res. 14, 272-278.

18. Brar, N.S., Saini, D.K., Kaushik, P., Chauhan, J., Kamboj, N.K., 2019. Directing for Higher Seed Production in Vegetables. Agronomy. https://doi.org/10.5772/intechopen.90646

19. Celine, V.A., Sirohi, P.S., 1996. Heterosis in bitter gourd (Momordica charantia L.). Veg. Sci. $23,180-85$.

20. Chakravarty, H.L., 1990. Cucurbits of India and their role in the development of vegetable crops. In: Bates, D.M., Robinson, R.W., Jeffrey, C. (Eds), Biology and utilization of cucurbitaceae. Cornell University Press, Ithaca, NY, pp 325-334.

21. Chaubey, A.K., Ram, H.H., 2004. Heterosis for fruit yield and its components in bitter gourd (Momordica charantia L.). Veg. Sci., 31, 51-53.

22. Chaudhari, S.M., Kale, P.N., 1991. Studies on heterosis in bitter gourd (Momordica charantia L.). Maharashtra J. Hort. 5, 45-51.

23. Cui, J., Luo, S., Niu, Y., Huang, R., Wen, Q., Su, J. et al., 2018. A RAD-Based Genetic Map for Anchoring Scaffold Sequences and Identifying QTLs in Bitter Gourd (Momordica charantia). Front. Plant Sci. 9:477. DOI: 10.3389/fpls.2018.00477.

24. Dalamu, Behera, T.K., Satyavati, C.T., Pal, A., 2012. Generation mean analysis of yield related traits and inheritance e fruit colour and surface in bitter gourd. Ind. J. Hort. 69, 65-69.

25. De Wilde, W.J.J.O., Duyfjes, B.E.E., 2002. Synopsis of Momordica (Cucurbitaceae) in South East Asia and Malaysia. Bot. Zhurn. 57, 132-148. 
26. Decker-Walters, D.S., 1999. Cucurbits, Sanskrit, and the Indo-Aryans. Econ. Bot. 53, 98-112.

27. Degner, O., 1947. Flora hawaiiensis, fifth ed. Privately published, Honolulu, 185 p.

28. Devdass, V.S., 1993. Genetic studies on fruit and seed yield and quality in bitter gourd (Momordica charantia L.), Ph.D. (Hort.) Thesis. Tamil Nadu Agricultural University, Coimbatore, India.

29. Dey, S.S., Behera, T.K., Munshi, A.D., Bhatia, R. 2009. Genetic variability, genetic advance and heritability in bitter gourd (Momordica charantia L.). Ind. Agri. 53, 7-12.

30. Dey, S.S., Behera, T.K., Munshi, A.D., Pal, A., 2010. Gynoecious inbred withbetter combing ability and earliness in bitter gourd (Momordica charantia L.). Euphytica 173, 37-47. DOI: 10.1007/s10681-009-0097-z.

31. Dey, S.S., Behera, T.K., Pal, A., Munshi, A.D., 2005. Correlation and path coefficient analysis in bitter gourd (Momordica charantia L.). Veg. Sci. 32, 173-176.

32. Dey, S.S., Singh, A.K., Chandel, D., Behera, T.K., 2006. Genetic diversity of bitter gourd (Momordica charantia L.) genotypes revealed by RAPD markers and agronomic traits. Sci. Hort. 109, 21-28.Doi: 10.1016/j.scientia.2006.03.006.

33. Dhillon, N.P.S., Phethin, S., Sanguansil, S., McCreight, J.D., 2017. Ealy, staminate flowering monoecious lines have potential as pollenizers for gynoecious hybrid bitter gourd cultivars. Pak. J. Agri. Sci. 54, 27-33. DOI:10.21162/PAKJAS/17.4354.

34. Dhillon, N.P.S., Sanguansil, S., Schafleitner, R., Wang, Y., McCreight, J.D., 2016. Diversity among a wide Asian collection of bitter gourd landraces and their genetic relationships with commercial hybrid cultivars. J. Amer. Soc. Hort. Sci. 141, 475-484. DOI: 10.21273/JASHS03748-16.

35. East, E.M., 1908. Inbreeding in corn. Conn. Agric. Exp. Sta. Rpt. 419-428.

36. Fan, Z., Robbins, M.D., Staub, J.E., 2006. Population development by phenotypic selection with subsequent marker-assisted selection for line extraction in cucumber (Cucumis sativus L.). Theor. Appl. Genet. 112, 843-855. https://doi.org/10.1007/s.00122-005-0186-x.

37. Fazio, G., Chung, S.M., Staub, J.E., 2003. Comparative analysis of response to phenotypic and marker-assisted selection for multiple lateral branching in cucumber (Cucumis sativus L.). Theor. Appl. Genet. 107, 875-883. https://doi.org/10.1007/s00122-003-1313-1.

38. Ferriol, M., Pico, B., Nuez, F., 2003. Genetic diversity of a germplasm collection of Cucurbita pepo using SRAP and AFLP markers. Theor. Appl. Genet. 107, 271-282. https://doi.org/10.1007/s00122-003-1242-z.

39. Gaikwad, A.B., Behera, T.K., Singh, A.K., Chandel, D., Karihaloo, J.L., Staub, J.E., 2008. Amplified fragment length polymorphism analysis provides strategies for improvement of bitter gourd (Momordica charantia L.). Hort Science 43, 127-133. DOI: 10.21273/HORTSCI.43.1.127.

40. Gaikwad, A.B., Saxena, S., Behera, T.K., Archak, S. Meshram, S.U., 2014. Molecular marker to identify gynoecious lines in bitter gourd. Ind. J. Hort. 71, 142-144.

41. Gangadhara Rao, P., Behera, T.K., Gaikwad, A.B., Munshi, A.D., Jat, G.S., Boopalakrishnan, G., 2018. Mapping and QTL analysis of gynoecy and earliness in bitter gourd (Momordica 
charantia L.) using genotyping-by-sequencing (GBS) technology. Front. Plant Sci. 9:1555. Doi: 10.3389/fpls.2018.01555.

42. Gao, S., Lin, B.Y., Xu, D.X., Fu, R.Q., Lin, F., Lin, Y.Z., Pan, D.M., 2010. Genetic diversity of bitter gourd (Momordica charantia L.) based on RAPD and ISSR. J. Plant Genet. Resour. $11,78-83$.

43. Guang-guang, L.I., Yan-song, Z., Xiang-yang, L.I., Zhang, H., Pei-guo, G., Hong-di, H., 2013. Genetic diversity analysis in bitter gourd germplasm resources based on SSR molecular markers. J. Southern Agri. 2013-01.

44. Gupta, P.K., Balyan, H.S., Sharma, P.C., Ramesh, B., 1996. Microsatellites in plants: a new class of molecular markers. Curr. Sci. 70, 45-54. https:www.jstor.org/stable/24097472

45. Han, J.S., Oh, D.G., Mok, I.G., Park, H.G., Kim, C.K., 2004. Efficient plant regeneration from cotyledon explants of bottle gourd (Lagenaria siceraria Stand1.). Plant Cell Rep.23, 291-296.

46. Haripriya, K. 1991., Heterosis and combining ability in watermelon (Citrullus lunatus Thumb. Mansf.). M. Sc. (Agri.) thesis, Tamilnadu Agricultural University, Coimbatore, India.

47. Hassena, N.B., Suhara, S.B., 2012. Characterization of interspecific F1 hybrids of Momordica charantia L. based on morphology, cytology and palynology. Cytologia 77, 301-310. DOI: 10.1508/cytologia.77.301.

48. Hoque, A., Islam, R., Joarder, O.I., 1995. "In vitro plantlets differentiation in kakrol (Momordica dioica Roxb.)". Plant Tissue Cult. 5, 119-124.

49. Hu, K.L., Fu Q.M., Wang, G.P., Mu, Z.H., 2002. Studies on the genetics of fruit color in bitter gourd (Momordica charantia L.). China Veg. 6, 11-12.

50. IARI. Annual Report 2018-19, Indian Agricultural Research Institute, New Delhi-110 012, India. www.iari.res.in

51. Islam, R., Sarkar, P.K., Naderuzzaman, A.T.M., Joarder, O.I., 1994. In vitro regeneration of plants from cotyledons of Momordica charantia L. Plant Tissue Cult. 4, 105-109.

52. Iwamoto, E., Hayashida, S., Ishida, T., Morita, T., 2009. Breeding and seasonal adaptability of high-female F1 hybrid bitter melon (Momordica charantia L.) 'Kumken BP1' using gynoecious inbred line for the seed parent. Hort. Res. 8, 143-147. DOI: 10.2503/hrj.8.143.

53. Iwamoto, E., Ishida, T., 2006. Development of gynoecious inbred line in balsam pear (Momordica charantia L.). Hort. Res. 5, 101-104. DOI: 10.2503/hrj.5.101.

54. Jadhav, B.P., Patil, M.B., Patil, S.Y., Halakude, I.S., Rajput, J.C., 2018. Development and maintenance of novel source of gynoecy in bitter gourd (Momordica charantia). Int. J. Curr. Res. 10, 63802-63805.

55. Jadhav, K.A., Garad, B.V., Dhumal, S.S., Kshirsagar, D.B., Patil, B.T., Shinde, K.G., 2009. Heterosis in bitter gourd. (Momordica charantia L.). Agri. Sci. Digest. 29, 7-11.

56. Joseph, J.K., 2005. Studies on ecogeography and genetic diversity of the genus Momordica L. in India. Dissertation, Mahatma Gandhi University, Kottayam, Kerala. 
57. Kandasamy, R., 2015. Heterosis in bitter gourd (Momordica charantia L.). Asian J. Hort. 10, 158-160.

58. Kathiravan, K., Vengedesan, G., Singer, S., Steinitz, B., Paris, H., Gaba, V. 2006. Adventitious regeneration in vitro occurs across a wide spectrum of squash (Cucurbita pepo) genotypes. Plant Cell Tissue Organ Cult. 85, 285-295. https://doi.org/10.1007/s11240-006-9079-1.

59. Kaushik, P., Andújar, I., Vilanova, S., Plazas, M., Gramazio, P., Herraiz, F.J., Brar, N.S., Prohens, J., 2015. Breeding Vegetables with Increased Content in Bioactive Phenolic Acids. Molecules 20, 18464-18481. https://doi.org/10.3390/molecules201018464

60. Khan, M.H., Bhuiyan, K.C., Saha, M.R., Ali, S.M.Y., 2015. Variability, correlation and path co-efficient analysis of bitter gourd (Momordica charantia L.). Bangladesh J. Agri. Res. 40, 607-618. https://doi.org/10.3329/bjar.v40i4.26936.

61. Khattra, A.S., Singh, N.J., Thakur, J.C. 1994. Studies on combining abilityin bitter gourd. Veg. Sci. 21, 158-62.

62. Kim, Z.H., Kim, Y.R., 1990. Inheritance of fruit weight in bitter-gourd (Momordica charantia L.). J. Korean Soc. Hort. Sci. 31, 238-246.

63. Kole, C., Bode, A.O., Kole, P., Rao, V.K., Bajpai, A., Backiyarani, S., 2012. The first genetic map and positions of major fruit trait loci of bitter melon (Momordica charantia). J. Plant Sci. Mol. Breed. 1, 1-6. https://doi.org/10.7243/2050-2389-1-1

64. Krishnamoorthy, H.N. 1975, Role of gibberellins in juvenility flowering and sex expression. In: Krishnamoorthy, H.N. (Eds.), Gibberellins and Plant Growth. Wiley Eastern Limited, New Delhi, pp. 115-143.

65. Krishnendu, J.R., Nandini, P.V., 2016. Nutritional composition of bitter gourd types (Momordica charantia L.). Int. J. Adv. Eng. Res. Sci. 3, 95-104. DOI: 10.22161/IJAERS/3.10.18.

66. Kumar, A., Sharma, V., Jain, B.T., Kaushik, P., 2020. Heterosis Breeding in Eggplant (Solanum melongena L.): Gains and Provocations. Plants (Basel) 9. https://doi.org/10.3390/plants9030403

67. Kumar, D., Pathak, M., 2018. Estimation of heterosis and combining ability for biochemical traits in bitter gourd (Momordica charantia L.). Int. J Chem. Stud. 6, 2579-2585.

68. Kumari, M., 2015. Physiological and molecular characterization of gynoecious line and genetics of fruit traits in Bitter gourd (Momordica charantia L.). Doctoral dissertation, Division of Vegetable Science Indian Agricultural Research Institute New Delhi), 2015.

69. Lawande, K.E., Patil, A.V., 1989. Studies on heterosis as influenced by combining ability on bitter gourd. Veg. Sci., 16, 49-55.

70. Liu, Z.G., Long, M.M., Qin, R.Y., Wang, X.Y., 2005. Studies on genetic variation, correlation and path analysis in bitter gourd (Momordica charantia L.). Guan. Bot. 25, 426-430.

71. Malik, S., Zia, M., Rehman, R., Chaudhary, F., 2007. In vitro plant regeneration from direct and indirect organogenesis of Momordica charantia. Pak. J. Biol. Sci. 10, 4118-4122. DOI: 10.3923/pjbs.2007.4118.4122.

72. Mallikarjunarao, K., Das, A.K., Nandi, A., Baisakh, B., Tripathy, P., Sahu, G.S., 2018. Heterosis and combining ability of quality and yield of bitter gourd (Momordica charantia L.). J. Pharm. Phytochem. 7, 05-09. 
73. Marr, K.L., Mei, X.Y., Bhattarai, N.K., 2004. Allozyme, morphological and nutritional analysis bearing on the domestication of Momordica charantia (cucurbitaceae). Econ. Bot. 58, 435455. https://doi.org/10.1663/0013-0001(2004)058[0435:AMANAB]2.0.C0;2.

74. Matsumura, H., Miyagi, N., Taniai, N., Fukushima, M., Tarora, K. 2014. Mapping of the gynoecy in bitter gourd (Momordica charantia L.) using RAD-Seq Analysis. PLoS ONE. 9(1):e87138. DOI: 10.1371/journal.pone.0087138.

75. Matsumura, H., Hsiao, M.-C., Toyoda, A., Taniai, N., Tarora, K., Urasaki, N., Anand, S.S., Dhillon, N.P.S., Schafleitner, R., Lee, C.-R., 2019. Long-read bitter gourd (Momordica charantia) genome and the genomic architecture of domestication. bioRxiv 822411. https://doi.org/10.1101/822411

76. Matsumura, H., Urasaki, N., 2020. Genome Sequence of Bitter Gourd and Its Comparative Study with Other Cucurbitaceae Genomes, in: The Bitter Gourd Genome. Springer, pp. 113123.

77. Melchinger, A.E., 1999. Genetic diversity and heterosis. In: Coors J.G., Pandey, S. (Eds). The genetics and exploitation of heterosis in crops. ASA, CSSA \& SSSA, Madison, WI.

78. Milbourne. D., Meyer, R., Bradshaw, J.E., Baired, E., Bonar, N., Provan, J. Powell, W., Waugh, R. 1997. Comparison of PCR-based marker systems for the analysis of genetic relationships in cultivated potato. Mol. Breed. 3, 127-136.

79. Miniraj, N., Prasanna, K.P., Peter, K.V., 1993. Bitter gourd (Momordica spp.). In: Kalloo G, Bergh, B.O. (Eds.), Genetic improvement of vegetable crops. Pergamon Press, Oxford, pp. 239-246.

80. Mishra, H.N., Mishra, R.S., Parhi, G., Mishra, N., 1998, Diallel analysis for variability in bitter gourd (Momordica charantia). Indian J. Agr. Sci. 68, 18-20.

81. Morgante, M., Olivieri, A., 1992. PCR-amplified microsatellites as markers in plant genetics. Plant J. 3, 175-182.

82. Munshi, A.D., Sirohi, P.S., 1993. Studies on heterosis in bitter gourd (Momordica charantia L.). Veg. Sci. 20, 147-151.

83. Oladosu, Y., Rafii, M.Y., Abdullah, N., Ghazali, H., Asfaliza, R., Rahim, H.A., Miah, G., Usman, M., 2016. Principle and application of plant mutagenesis in crop improvement: A review. Biotechnol. Biotechnol. EquiP.. 30, 1-16. DOI: 10.1080/ 13102818.2015.1087333.

84. Peakall, R., Gilmore, S., Keys, W., Morgante, M., Rafalski, A., 1998. Cross-species amplification of Soybean (Glycine max) simple sequence repeats (SSRs) within the genus and other legume genera: Implications for the transferability of SSRs in plants. Mol. Boil. Evol. 15, $1275-1287$.

85. Penna, S., Vitthal, S.B., Yadav, P.V., 2012. In vitro mutagenesis and selection in plant tissue cultures and their prospects for crop improvement. Global Science Book. 6, 6-14. 
86. Powell, W., Morgante, M., Andre, C., Hanafe, M., Vogel, J., Tingey, S.V., Rafalski, A.., 1996. The comparison of RFLP, RAPD, AFLP and SSR (microsatellite) markers for germplasm analysis. Mol. Breed. 2, 225-238.

87. Rajasekharan, K.R., Shanmugavelu, K.G., 1984. MDU-I bittergourd. South Indian Hortic. 32, 47.

88. Ram, D., Kalloo, G., Singh, M., 1997a. Heterosis in bitter gourd (Momordica charantia L.). Veg. Sci. 24, 99-102

89. Ram, D., Kumar, S., Banerjee, M.K., Kalloo, G., 2000. Occurance, identification and preliminary characterization of gynoecium in bitter gourd (Momordica charantia L.). Int. J. Agri. Sci. 72, 348-349.

90. Ram, D., Kumar, S., Banerjee, M.K., Kalloo, G., 2002a. Occurrence, identification and preliminary characterisation of gynoecism in bitter gourd (Momordica charantia L.). Indian J. Agri. Sci. 72, 348-349.

91. Ram, D., Kumar, S., Banerjee, M.K., Singh, B., Singh, S., 2002b. Developing bitter gourd (Momordica charantia L.) populations with very high proportion of pistillate flowers. Cucurbit. Genet. Coop. Rep. 25, 65-66.

92. Ram, D., Kumar, S., Singh, M., Rai, M., Kalloo, G., 2006. Inheritance of gynoecism in bitter gourd (Momordica charantia L.). J. Heredit. 97, 294-295. DOI: 10.1093/jhered/esj028.

93. Ranpise, S.A., Kale, P.N., Deysale, G.Y., Desai, U.T., 1992. Heterosis in bitter gourd. South Indian Hort. 40, 313-315.

94. Rathod, V., Behera, T.K., Munshi, A.D., Vinod, Jat, G.S. 2019. Crossability studies among Momordica charantia var. charantia and Momordica charantia var. muricata. Ind. J. Agri. Sci. 89, 1900-1905.

95. Rathod, V., Narasegowda, N.C., Papanna, N., Simon, L., 2008. Evaluation of genetic diversity and genome fingerprinting of bitter gourd genotypes (Momordica charantia L.) by morphological and RAPD markers. Intl J. Plant. Breed. 2, 79-84.

96. Richard, K.R., Arumugam, R., Kandasamy, G., Suresh, S., 1995. Heterosis studies in bitter gourd. Madras Agril. J. 82, 121-123.

97. Robinson, R.W., Decker-Walters, D.S., 1997. Cucurbits (CABI Publishing, Cambridge, MA).

98. Saha, S., Behera, T.K.., 2015. Standardization of Techniques for in vitro Multiplication of Gynoecious Line in Bitter Gourd. Int. J. plant Res. 28, 48. DOI: 10.5958/22294473.2015.00083.X

99. Saxena, S., Singh, A., Archak, S., Behera, T.K., Joahn, J.K., Meshram, S.U., Gaikwad, A.B., 2014. Development of novel simple sequence repeat markers in bitter gourd (Momordica charantia L.) through enriched genomic libraries and tehir utilization in analysis of genetic diversity and cross-species transferability. Appl. Biochem. Biothechnol https:// doi.org/10.1007/s12010014-1249-8. 
100. Schaefer, H., Renner, S.S., 2010. A three-genome phylogeny of Momordica (Cucurbitaceae) suggests seven returns from dioecy to monoecy and recent long-distance dispersal to Asia. Mol. Phylogenet. Evol. 54, 553 560. DOI: 10.1016/j.ympev.2009.08.006.

101. Shang, J., Kong, S., Li, N., Wang, J., Zhou, D., Li, N., Ma, S., 2020. Genetic mapping and localization of major QTL for bitterness in melon (Cucumis melo L.). Sci. Hort. 266, 109286.

102. Shull, G.H., 1908. The composition of a field of maize. Am. Breeders Assoc. Rep. 4, 296-301.

103. Shull, G.H., 1914. Duplicated genes for capssule form in Bursa bursa-pastoris. Z. Indukt. Abstammungs u. Verebungsl. 12, 97-149.

104. Sikdar, B., Shafiullah, M., Chowdhury, A.R., Sharmin, N., Naha, S., Joarder, O.I., 2005. Agrobacterium-mediated GUS expression in bitter gourd (M. charantia L.). Biotechnol. 4, 149-152. DOI: 10.3923/biotech.2005.149.152.

105. Singh, A.K., 1990. Cytogenetics and evolution in the cucurbitaceae. In: Bates, D.M., Robinson, R.W., Jeffrey, C. (Eds), Biology and utilization of Cucurbitaceae. Comstock Publishing Associates, Cornell University Press, Ithaca, New York and London, pp. 10-28.

106. Singh, A.K., Behera, T.K., Chandel, D., Sharma, P., Singh, N.K., 2007. Assessing genetic relationships among bitter gourd (Momordica charantia L.) accessions using inter simple sequence repeat (ISSR) markers. J. Hort. Sci. Biotechnol. 82, 217-222. https:// doi.org/10.1080/14620316.2007.11512222.

107. Singh, A.K., Pandey, U.B., Singh, M. 2000. Studies on heterosis in bitter gourd. Veg Sci. 27, 158-161.

108. Singh, B., Joshi, S., 1980. Heterosis and combining ability in bitter gourd. Indian J. Agric. Sci., 50, 558-551.

109. Singh, N.J., Khattra, A.S., Thakur J.C., 1997. Heterobeltosis in bitter gourd. Haryana J. Hort. Sci. 26, 291-296.

110. Singh, N.J., Khattra, A.S., Thakur, J.C., 2001. Studies on heterosis in bitter gourd (Momordica charantia L.). Haryana J. Hort. Sci. 30, 224-227.

111. Singh, S.K., Ram, H.H., 2005. Seed quality attributes in bitter gourd (Momordica charantia L.). Seed Res. 33, 92-95.

112. Sinha, S., Sandhu, K., Bisht, N., Naliwal, T., Saini, I., Kaushik, P., 2019. Ascertaining the Paradigm of Secondary Metabolism Enhancement through Gene Level Modification in Therapeutic Plants. Journal of Young Pharmacists 11, 337-343. https://doi.org/10.5530/jyp.2019.11.70

113. Sirohi, P.S., Choudhary, B., 1978. Heterosis in bitter gourd (Momordica charantia L.). Veg. Sci., 4, 107-115.

114. Smith, A.C., 1981. Flora vitiensis nova. SB Printers, Honolulu, HI.

115. Srivastava, N., 1976. Floragorakpurensis. Today and tommorrow Publishers, New Delhi, P. 149.

116. Srivastava, V.K., Nath, P., 1972. Inheritance of some qualitative characters in Momordica charantia L., Indian J. Hortic. 29, 319. 
117. Suribabu, B., Reddy, N.E., Ramarao, M., 1986. Inheritance of certain quantitative and qualitative characters in bittergourd (Momordia charantia L.), South Indian Hortic. 34, 380.

118. Talekar, N.S., Vaddoria, M.A., Kalkaran, G.V., 2013. Heterosis studies for quantitative traits in bitter gourd (Momordica charantia L.) Progressive Res. 8, 650-653.

119. Talukdar, M.B., Rahman, M.M., Islam, M.K., Rahman, K.A.M.M., Hossen, M.A., 2010. Estimate of heterosis in bitter gourd. J. Sher-e-Bangla Agric, Univ. 4, 73-79.

120. Tewatia, A.S., Dhankar, B.S., 1996. Inheritance of resistance to melon fruit fly (Bactrocera cucurbitae) in bitter gourd (Momordica charantia L.). Ind. J. Agri. Sci. 66, 617620 .

121. Thangamani, C., Pugalendhi, L., 2013. Heterosis studies in bitter gourd for yield and related characters. Int. J. Veg. Sci. 19, 119-25. DOI: 10.1080/19315260.2012.677115.

122. Thangamani, C., Pugalendhi, L., Sumathi, T., Kavitha, C. Rajashree, V., 2011. Estimation of combining ability and heterosis for yield and quality characters in bitter gourd (Momordica charantia L.). Electronic J. P1. Breed. 2, 62-66.

123. Thiruvengadam, M., Praveen, N., Chung, I.M., 2012. An efficient Agrobacterium tumefaciens-mediated genetic transformation of bitter melon (Momordica charantia L.). Aust. J. Crop Sci. 6, 1094-1100.

124. Thiruvengadam, M., Varisai Mohamed, S., Yang, C.H., Jayabalan, N., 2006. Development of an embryogenic suspension culture of bitter melon (Momordica charantia L.). Sci. Hortic. 109, 123-129. https://doi.org/10.1016/jscienta.2006.03.012.

125. Thiruvengadam, M., Yang, C.H., 2009. Ectopic expression of two MADS box genes from orchid (Oncidium Gower Ramsey) and lily (Lilium longiflorum) alters flower transition and formation in Eustoma grandiflorum. Plant Cell Rep. 28, 1463-1473. DOI: 10.1007/s00299009-0746-7.

126. Trivedi, R.N., Roy, R.P., 1972. Cytological studies in some species of Momordica. Genetica, 43, 282-291.

127. Urasaki, N., Takagi, H., Natsume, S., Uemura, A., Taniai, N., Miyagi, N., Fukushima, M., Suzuki, S., Tarora, K., Tamaki, M., 2017. Draft genome sequence of bitter gourd (Momordica charantia), a vegetable and medicinal plant in tropical and subtropical regions. Dna Research 24, 51-58.

128. Vahab, M.A., 1989. Homeostatic analysis of components of genetic variance and inheritance of fruit colour, fruit shape, and bitterness in bitter gourd (Momordica charantia L.). Ph.D. Thesis, Kerala Agri Univ, India.

129. Varalakshmi, B., Pitachaimuthu, M., Rao, E.S., Krishnamurthy, D., Suchitha,Y., Manjunath, K.S.S, 2014. Identification preliminary characterization and maintenance of gynoecious plants, IIHRBTGy-491 and IIHRBTGy-492 in bitter gourd. In the international Bitter gourd Conference (BiG2014) organized by AVRDC at ICRISAT, Hyderabad in March, 36.

130. Verma, R.S., Pratap, N., Shekhar, R., Sing, R.P., Vishnoi, R.K., 2016. Exploitation of heterosis for yield and its components in bitter gourd (Momordica charantia L.). Plant Arch. $16,403-412$. 
131. Verma, R.S., Singh, M.K., 2014. Studies on heterosis for yield and its components of bitter gourd (Momordica charantia L.). Asian J. Hort., 9, 217-223.

132. Vos, P., Hogers, R., Bleeker, M., Reijans, M., Van de Lee, T., Hornes, M., Frijters, A., Pot, J., Peleman, J., Kuiper, M., Zabeau, M., 1995. AFLP: a new technique for DNA fingerprinting. Nucleic Acid Res. 18, 7213-7218.

133. Walters, T.W., Decker-Walters, D.S., 1988. Balsam-pear (Momordica charantia, Cucurbitaceae). Econ. Bot. 42, 286-292.

134. Wang, G.L., Fan, H.Y., Lin, R.Y., Li, X.T., 2008. Establishiment of in vitro regeneration system of Momordica charantia L. with different genotype. J. An. Hui Agric. Sci. $36,12125-12127$.

135. Wang, S., Tang, L. Chen, F., 2001. In vitro flowering of bitter melon. Plant Cell Reports, 20, 393-397.

136. Wang, Z., Xiang, C., 2013. Genetic mapping of QTLs for horticulture traits in a F2-3 population of bitter gourd (Momordica charantia L.). Euphytica 193, 235-250. https://doi.org/10.1007/s10681-013-0932-0

137. Xie, F.M., He, Z.Z., Esguerra, M.Q., Qiu, F.L., Ramanathan, V. 2013. Determinationof heterotic groups for tropical Indica hybrid rice germplasm. Theo. Appl. Genet. 127, 407-417. DOI: $10.1007 / \mathrm{s} 00122-013-2227-1$.

138. Yadav, M., Chaudhary, R., Singh, D.B., 2009. Heterosis in bitter gourd (Momordica charantia L.). J. Hortl. Sci. 4, 170-173.

139. Yilmaz, S.S., Khawar, K.M., 2020. Tissue Culture, Genetic Engineering, and Nanotechnology in Bitter Gourd, in: The Bitter Gourd Genome. Springer, pp. 83-89.

140. Yang, S.L., Walters, T.W., 1992. Ethnobotany and the economic role of the Cucurbitaceae of China. Econ. Bot. 46, 349-367.

141. Yashodhara, V., Muralikrishna, N. Raghu, E., Bharathkumar, K., Rathnaprabha, D., Sadnandam, A., 2016. In vitro plant regeneration from petiole explants and assessments of genetic fidelity using ISSR markers in Momordica charantia L. Plant Cell Biotechnol. Mol. Biol. 17, 49-56.

142. Yen, D.E., 1977. The evidences and questions from Northwest Thiland. Pages 567-599 in Allen J. Golson and R Jones, eds., Sunda and Sahel. Prehistoric studies in South-east Asia, Malenesia and Australia. Academic Press, London. 